University of Nebraska - Lincoln

DigitalCommons@University of Nebraska - Lincoln

Faculty Papers and Publications in Animal

Science

Animal Science Department

$1-14-2003$

\title{
Models with cytoplasmic effects for birth, weaning, and fleece weights, and litter size at birth for a population of Targhee sheep
}

\author{
L. Dale Van Vleck \\ University of Nebraska-Lincoln, dvan-vleck1@unl.edu
}

G. D. Snowder

USDA, ARS, U.S. Sheep Experiment Station, Dubois, ID

Kathryn J. Hanford

University of Nebraska, kathy.hanford@unl.edu

Follow this and additional works at: https://digitalcommons.unl.edu/animalscifacpub

Part of the Animal Sciences Commons

Van Vleck, L. Dale; Snowder, G. D.; and Hanford, Kathryn J., "Models with cytoplasmic effects for birth, weaning, and fleece weights, and litter size at birth for a population of Targhee sheep" (2003). Faculty Papers and Publications in Animal Science. 199.

https://digitalcommons.unl.edu/animalscifacpub/199

This Article is brought to you for free and open access by the Animal Science Department at DigitalCommons@University of Nebraska - Lincoln. It has been accepted for inclusion in Faculty Papers and Publications in Animal Science by an authorized administrator of DigitalCommons@University of Nebraska - Lincoln. 


\title{
Models with cytoplasmic effects for birth, weaning, and fleece weights, and litter size at birth for a population of Targhee sheep ${ }^{1}$
}

\author{
L. D. Van Vleck ${ }^{* 2}$, G. D. Snowder $\dagger^{3}$, and K. J. Hanford* \\ *USDA, ARS, U.S. Meat Animal Research Center, Lincoln, NE 68583-0908 and †USDA, ARS, \\ U.S. Sheep Experiment Station, Dubois, ID 83423
}

\begin{abstract}
Fifteen models were compared for the birth weight of 33,994 lambs recorded at the U.S. Sheep Experimental Station (1950 to 1998). The initial intent was to estimate fractions of variance due to cytoplasmic line $\left(\mathrm{c}^{2} ; \mathrm{n}=892\right)$ and sire by cytoplasmic line interaction $\left(\mathrm{sc}^{2} ; \mathrm{n}=17,557\right)$. The basic model included direct genetic (fractional variance, $\mathrm{a}^{2} ; \mathrm{n}=35,684$ ), maternal genetic $\left(\mathrm{m}^{2}\right.$, with correlation $\mathrm{r}$-am), and maternal permanent environmental $\left(\mathrm{p}^{2} ; \mathrm{n}=8,418\right)$ effects. The model with $\mathrm{sc}^{2}$ was significantly better than the basic model with and without $c^{2}$. When other random effects were added, $\mathrm{sc}^{2}$ became zero. Significant effects were associated with random dam $\times$ year $\left(\mathrm{dy}^{2} ; \mathrm{n}=24,801\right)$, sire $\times$ dam $\left(\mathrm{sd}^{2} ; \mathrm{n}=23,924\right)$, and dam $\times$ number born $\left(\mathrm{dn}^{2} ; \mathrm{n}=\right.$ $12,944)$ interaction effects. Estimates with all effects in the model were $\mathrm{a}^{2}, 0.24 ; \mathrm{m}^{2}, 0.19 ; \mathrm{r}$-am, $0.11 ; \mathrm{p}^{2}$, $0.05 ; \mathrm{c}^{2}, 0.00 ; \mathrm{dn}^{2}, 0.04 ; \mathrm{dy}^{2}, 0.06 ; \mathrm{sd}^{2}, 0.05 ; \mathrm{sc}^{2}, 0.00$. Estimates for $\mathrm{a}^{2}, \mathrm{~m}^{2}$, and $\mathrm{r}$-am were the same for all models. Estimate of $\mathrm{p}^{2}$ changed when other effects were
\end{abstract}

added to the model. Largest estimates for nongenetic effects were: $\mathrm{p}^{2}, 0.08 ; \mathrm{c}^{2}, 0.00 ; \mathrm{dy}^{2}, 0.13 ; \mathrm{sd}^{2}, 0.11$; and $\mathrm{sc}^{2}, 0.04$. Regardless of whether Westell groups $(\mathrm{n}=91)$ were in the model, estimates were similar. For weaning weight (120-d, $\mathrm{n}=32,715)$, estimates of variances of effects added to the basic model were all near zero $\left(\mathrm{a}^{2}\right.$, $\left.0.18 ; \mathrm{m}^{2}, 0.12 ; \mathrm{r}-\mathrm{am},-0.01 ; \mathrm{p}^{2}, 0.06\right)$. For number born $(\mathrm{NB}, \mathrm{n}=37,020)$ and fleece weight $(\mathrm{FW}, \mathrm{n}=36,197)$, animal permanent environmental effects were added to the model $\left(\mathrm{ap}^{2} ; \mathrm{n}=9,871\right.$ and 9,760) and $\mathrm{r}$-am was dropped. For these traits, effects not in the basic model had small variances. Nonzero estimates with full model were $\mathrm{a}^{2}, 0.10 ; \mathrm{ap}^{2}, 0.01 ; \mathrm{dy}^{2}, 0.02$; and $\mathrm{sc}^{2}, 0.01$ for NB, and $\mathrm{a}^{2}, 0.54 ; \mathrm{m}^{2}, 0.02 ; \mathrm{ap}^{2}, 0.02 ; \mathrm{dy}^{2}, 0.04 ;$ and $\mathrm{sc}^{2}, 0.02$ for FW. Cytoplasmic effects were not important. The addition of unusual random effects to the model did not change estimates for the basic parameters. Although some of these effects were significant, especially for BW, the effects on genetic evaluations are likely to be small.

Key Words: Cytoplasmic Inheritance, Environment Interactions, Genetic Variance, Genotype

(C2003 American Society of Animal Science. All rights reserved.

J. Anim. Sci. 2003. 81:61-67

\section{Introduction}

Studies of cytoplasmic effects on quantitative traits of cattle have generally followed the pattern of initially showing importance followed by increasingly sophisticated statistical analyses, which have shown little importance for dairy cattle (Bell et al., 1985; Boettcher and Gibson, 1997; and Albuquerque et al., 1998) and beef cattle (Tess et al., 1987; and Tess and Robison, 1990). Maniatis and Pollott (2002) recently found no

\footnotetext{
${ }^{1}$ Published as paper no. 13711, Journal Ser., Nebraska Agric. Res. Div., Univ. of Nebraska, Lincoln 68583-0908.

${ }^{2}$ Correspondence: A218 Animal Sciences, Univ. of Nebraska, Lincoln 68583-0908 (phone: 402-472-6010; fax: 402-472-6362; E-mail: dvan-vleck@unl.edu).

${ }^{3}$ Current address: U.S. Meat Animal Research Center, P.O. Box 166, Clay Center, NE 68933.

Received May 16, 2002.

Accepted August 20, 2002.
}

evidence of cytoplasmic effects on weight traits of Suffolk lambs. Kennedy (1986), using simulation data, showed that not accounting for genetic drift could result in overestimation of variance due to cytoplasmic line. Specific mitochondrial types have been reported to influence milk production in dairy cattle (Schutz et al., 1994, and Boettcher et al., 1996) and carcass traits in Japanese Black cattle (Mannen et al., 1998). Interactions of mitochondrial and nuclear genomes have been identified in humans (Wolz et al., 1997) and cattle (Seelan and Grossman, 1992).

Although quantitative traits of sheep would also not be expected to be influenced by cytoplasmic effects, such studies are rare. The purpose of this study was to estimate variance due to cytoplasmic effects and due to genotype by cytoplasmic effects for four representative traits for Targhee sheep. A secondary goal was to study the effect of including a parent $($ dam $) \times$ year effect in the model on estimates of genetic parameters. Studies with beef cattle have shown that including sire $\times$ year interaction effects in the model changes the estimate 
Table 1. Summary of number of records and of levels by factor for four traits of Targhee sheep ${ }^{a}$

\begin{tabular}{lcccr}
\hline \hline Number & Birth weight & Wean weight & Fleece weight & No. born \\
\hline Records $^{\mathrm{b}}$ & 33,994 & 32,715 & 36,195 & 37,020 \\
$\quad$ Mean, wt., kg & 4.90 & 34.6 & 4.93 & 1.32 \\
SD, wt., kg & 0.83 & 6.2 & 0.96 & 0.71 \\
Animals with records & 33,994 & 32,715 & 9,760 & 9,871 \\
Sires & 1,535 & 1,534 & 1,368 & 1,369 \\
Dams & 8,418 & 8,356 & 5,256 & 5,288 \\
Cytoplasmic line & 892 & 892 & 581 & 588 \\
Dam $\times$ year & 24,801 & 24,466 & 8,961 & 9,060 \\
Sire $\times$ dam & 23,924 & 23,604 & 8,822 & 8,920 \\
Sire $\times$ cytoplasmic line & 17,557 & 17,380 & 7,467 & 7,538 \\
Dam $\times$ number born & 12,944 & - & - & - \\
\hline
\end{tabular}

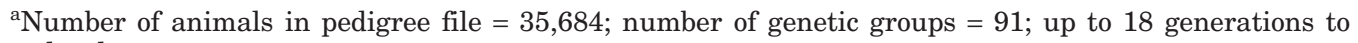
founder dam.

${ }^{\mathrm{b}}$ Means and standard deviations are not adjusted for fixed or random factors.

of the direct-maternal genetic correlation and may indicate misidentification of sires from year to year (Robinson, 1996; Lee and Pollak, 1997; and Dodenhoff et al., 1999). Hagger (1998) has reported a similar result for early gain in two Swiss breeds of sheep. In these data, sires did not repeat over years, but dams did. Estimates of genetic parameters for birth weight with dam $\times$ year effects in the model led to the use of several unusual models.

\section{Materials and Methods}

Data from the Targhee flock located at the U.S. Sheep Experiment Station in Dubois, Idaho, were available from 1950 through 1998. Hanford (2001) had previously edited the data for estimation of genetic parameters needed to assess genetic change over the $49 \mathrm{yr}$ for seven traits. That thesis and data from Ercanbrack and Knight (1991) also describe the origin of the Targhee flock, general management of the flock, and the method used to adjust weaning weights to the standard 120d age.

Summaries of means and the number of levels of factors describing the data for birth weight, weaning weight (120 d), and fleece weight (repeated annual measurements) of ewes and the number of lambs born per ewe (repeated annual measurements) are shown in Tables 1 and 2. Fixed factors for the analyses are described in Table 2.

Birth weight was the first trait analyzed. Initial models included direct and maternal genetic (with covariance), maternal permanent environmental, and residual environmental effects, as well as cytoplasmic line effects. Cytoplasmic lines were defined by tracing all animals through the female line of descent to unique founding dams. The number of cytoplasmic lines ranged from 581 to 892 , depending on the trait. The data were truncated in 1950, so pedigrees ending in 1950 might, if extended, be traced to fewer founding dams. The interaction of genotype $\times$ cytoplasmic line effects or the interaction of nuclear $\times$ mitochrondrial genomes was studied by including a random effect for sire $\times$ cytoplasmic line combination, since sires were mated to ewes from various cytoplasmic lines. The final part of the initial model was to include a dam $\times$ year interaction effect. Sires were not repeated over years, but dams were. The intent was to determine if including such a factor would affect estimates of genetic parameters, including the direct-maternal genetic correlation.

Unexpectedly for birth weight, the estimate of the component of variance for dam $\times$ year effects was large $(\sim 10 \%)$. On reflection, that did not seem reasonable since the only way a dam could have more than one measure in a year was to have multiple births in at least $1 \mathrm{yr}$. Therefore, two other interactions were added to the model: $\operatorname{dam} \times$ number born and sire $\times$ dam. These effects would be expected to be highly confounded and also confounded with levels of dam $\times$ year, as can be seen in Table 1. In general, cytoplasmic line effects were found not to be important, and emphasis was put on investigating the confounded factors for birth weight. The other traits were analyzed later.

Fewer models were used for the other traits because of the time required for the analyses and because cytoplasmic line effects had essentially zero variances. For traits with repeated measures (number born and fleece weight), animal and maternal permanent environmental effects were both included in some models. The final

Table 2. Number of levels for fixed factors in models for analysis of four traits (Targhee) ${ }^{a}$

\begin{tabular}{lcccc}
\hline \hline Factor & BWT & WWT & FLW & NB \\
\hline Year & 49 & 49 & 46 & 47 \\
Age of dam (ewe) & 12 & 12 & $(14)$ & $(14)$ \\
Gender & 3 & 3 & - & - \\
Type of birth (TB) & 4 & - & - & - \\
TB and rearing & - & 8 & - & - \\
Number weaned & - & - & 4 & - \\
Calendar day (covariate) & - & - & $\checkmark$ & - \\
\hline
\end{tabular}

${ }^{a}$ BWT = birth weight; WWT = wean weight; FLW = fleece weight; $\mathrm{NB}=$ No. born. 
Table 3. Possible random factors in models for analyses of four traits (Targhee)

\begin{tabular}{lcccc}
\hline \hline Factor & BWT & WWT & FLW & NB \\
\hline Animal genetic, $\mathrm{a}^{2}$ & $\checkmark$ & $\checkmark$ & $\checkmark$ & $\checkmark$ \\
Maternal genetic, $\mathrm{m}^{2}$ & $\checkmark$ & $\checkmark$ & $\checkmark$ & $\checkmark$ \\
Correlation, $\mathrm{ram}$ & $\checkmark$ & $\checkmark$ & - & - \\
Maternal permanent environmental, $\mathrm{p}_{\mathrm{M}}^{2}$ & $\checkmark$ & $\checkmark$ & $\checkmark$ & $\checkmark$ \\
Animal permanent environmental, $\mathrm{p}_{\mathrm{A}}^{2}$ & - & - & $\checkmark$ & $\checkmark$ \\
Cytoplasmic line, $\mathrm{c}^{2}$ & $\checkmark$ & $\checkmark$ & $\checkmark$ & $\checkmark$ \\
Dam $\times$ year, dy & $\sqrt{ }$ & $\checkmark$ & $\checkmark$ & $\checkmark$ \\
Dam $\times$ number born, $\mathrm{dn}^{2}$ & $\checkmark$ & - & $\checkmark$ & $\checkmark$ \\
Sire $\times$ dam, $\mathrm{ds}^{2}$ & $\checkmark$ & $\checkmark$ & $\checkmark$ & $\checkmark$ \\
Sire $\times$ cytoplasmic line, $\mathrm{sc}^{2}$ & $\checkmark$ & $\checkmark$ & & \\
\hline
\end{tabular}

${ }^{\mathrm{a} B W T}=$ birth weight; WWT $=$ wean weight; FLW $=$ fleece weight; NB $=$ No. born.

comparison was for analyses with founder genetic groups included as fixed effects (Westell et al., 1988). These groups were formed by Hanford (2001) based on when outside rams entered the flock. The full (and most of the reduced) models resulted in similar estimates for genetic parameters, regardless of whether the groups were in the model. Therefore, to reduce duplication and computational time, the other models were not used with founder genetic groups in the model. The random factors used for the four traits are summarized in Table 3 .

Estimates of variance components were by restricted maximal likelihood with a derivative-free algorithm (Smith and Graser, 1986) using the multiple-trait restricted maximal likelihood programs (Boldman et al., 1995). Standard errors for genetic parameters and for fractions of variance due to other factors were computed using the delta method and the average information matrix at convergence (e.g., Dodenhoff et al., 1998). Differences in twice the natural logarithm of the likelihood given the data, the basis for the likelihood ratio test (LRT), were used to compare models with degrees of freedom equal to the difference in number of dispersion parameters in the models.

\section{Results}

\section{Birth Weight}

Estimates from 15 models are given in Table 4. Some of these results can be summarized briefly. Models with (rows 1 and 2) and without fixed genetic group effects gave results that were similar (row 1 vs row 3 ; row 2 vs row 15). All models resulted in similar estimates for direct and maternal heritabilities and for the directmaternal genetic correlation. Variance due to cytoplasmic lines was not significant and near zero. Adding a dam $\times$ year interaction (with or without cytoplasmic lines in the model) accounted for an additional $10 \%$ of the total variance $\left(\mathbf{e}^{2}\right.$, the fraction of variance due to residual effects, was reduced from 0.45 to 0.35 ), with only a slight reduction in the proportion of variance due to maternal permanent environmental effects $\left(\mathbf{p}^{\mathbf{2}}\right)$. In an attempt to understand the magnitude of esti- mates of variance due to dam $\times$ year effects, dam $\times$ number born was included as a random factor. The fit of the model with dam $\times$ number born in the model was not nearly as good as that with dam $\times$ year effects in the model. The proportion of variance due to dam by number born $\left(\mathbf{d n}^{2}\right)$ was partitioned largely from variance due to maternal permanent environmental effects. Including both dam $\times$ year and dam $\times$ number born, however, further improved the fit of the data to the model with a highly significant LRT. In this case, variance due to dam $\times$ number born seemed to account for some of variance due to maternal permanent environmental effects and some of variance due to dam $\times$ year effects. Adding sire $\times$ dam effects to the model improved the basic model, as was expected due to obvious confounding with dam $\times$ year effects, although the improvement in the log likelihood was not as much as with dam $x$ year effects. The estimate of fractional variance of 0.11 would suggest a fractional estimate of dominance variance of about 0.40 , which is much too large. When included in the model, however, with dam $\times$ year or with dam $\times$ year and dam $\times$ number born effects, the estimate of fractional variance due to sire $\times$ dam effects was reduced to a more reasonable 0.05 . The addition of sire $\times$ cytoplasmic line effects to the basic model resulted in a significant improvement, but the improvement was less than adding the other interaction effects. The estimate of 0.04 for fraction of total variance was reduced to near zero when the other interaction effects were also included in the model. The proportion of variance due to sire by cytoplasmic line interaction effects does not seem to be partitioned from variance due to maternal permanent environmental effects. Although confounding exists among the dam $\times$ year, dam $\times$ number born, and sire $\times$ dam effects, the best model includes all three factors as additions to the basic direct-maternal model. The results suggest that cytoplasmic line and sire by cytoplasmic line effects contribute little to variation in birth weight.

Al-Shorepy and Notter (1998) have reported that litter effects (comparable to the dam $\times$ year effect) accounted for about $17 \%$ of variation in birth weight. D. Notter (personal communication) reported that unpublished results from Targhee, Suffolk, and Polypay sheep 
Table 4. Estimates of genetic parameters ${ }^{\mathrm{a}}$ for birth weight with 15 models with SE for complete model $^{\mathrm{b}}$ on bottom row

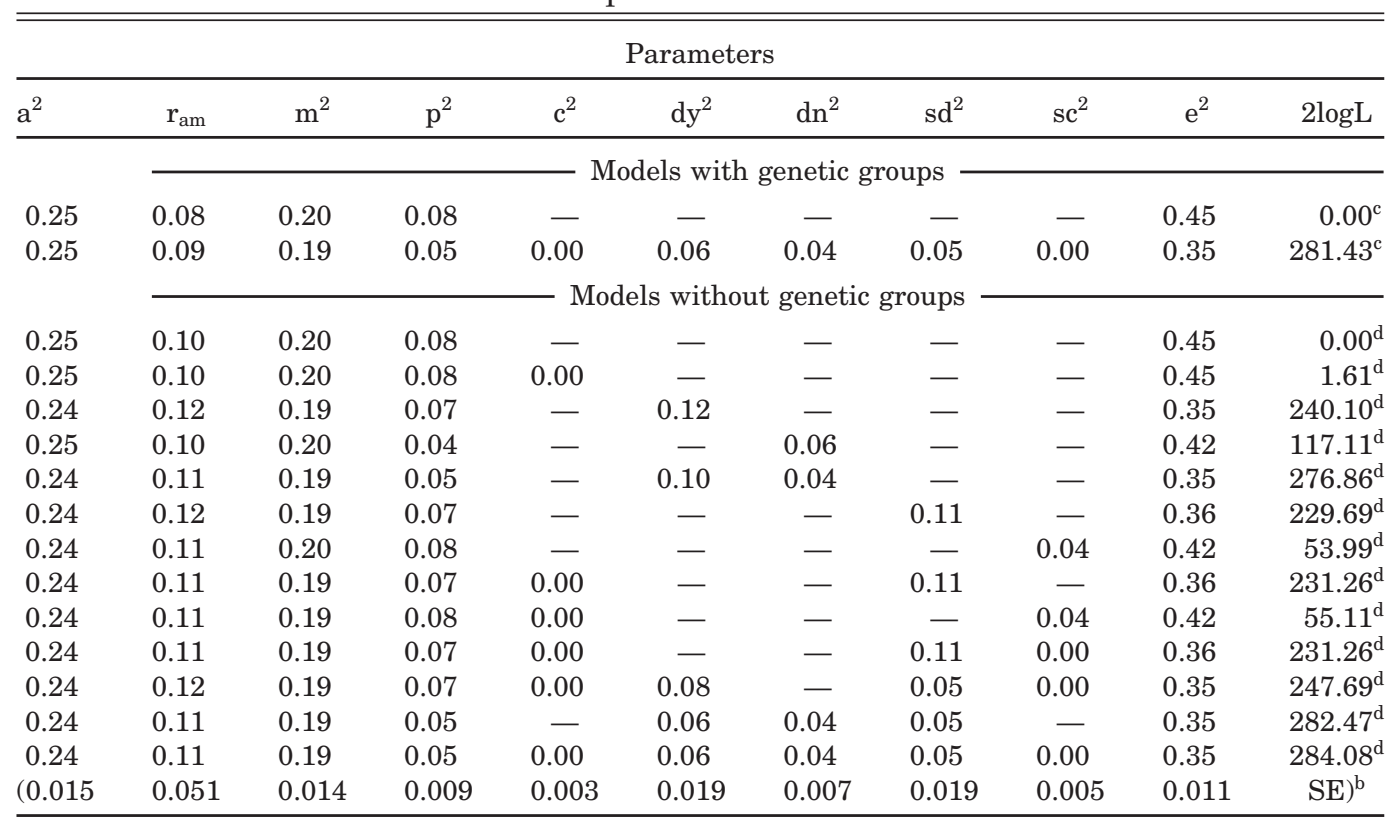

aproportional variance: $\mathrm{a}^{2}=$ direct genetic; $\mathrm{r}_{\mathrm{am}}=$ direct-maternal genetic correlation; $\mathrm{m}^{2}=$ maternal genetic; $\mathrm{p}^{2}=$ maternal permanent environmental; $\mathrm{c}^{2}=$ cytoplasmic line; $\mathrm{dy}^{2}=$ dam $\times$ year; $\mathrm{dn}^{2}=$ dam $\times$ number born; $\mathrm{sd}^{2}=$ sire $\times$ dam; $\mathrm{sc}^{2}=$ sire $\times$ cytoplasmic line; $\mathrm{e}^{2}=$ temporary environmental. Phenotypic variance: 0.4752 to $0.4787 \mathrm{~kg}^{2}$.

${ }^{\mathrm{b}}$ Complete model not including genetic groups.

${ }^{\mathrm{c}}$ Difference in 2log likelihood from usual model $\left(\mathrm{a}^{2}, \mathrm{r}_{\mathrm{am}}, \mathrm{m}^{2}, \mathrm{p}^{2}\right)$ with genetic groups in model.

${ }^{\mathrm{d}}$ Difference in $2 \log$ likelihood from usual model $\left(\mathrm{a}^{2}, \mathrm{r}_{\mathrm{am}}, \mathrm{m}^{2}, \mathrm{p}^{2}\right)$ with genetic groups not in model.

included in the National Sheep Improvement Program also show large and significant components of variance for litter effects. A reviewer suggested that much of the variance due to dam $\times$ year and dam $\times$ number born effects may be due to a year-specific environmental effect on lambs in the same litter (i.e., if those effects result in light or heavy birth weight for one member of the litter, weights of others in the litter will be similar).

\section{Weaning Weight}

The next trait analyzed was weaning weight, with the expectation that the estimates would follow the same pattern as birth weight. The results, however, were different, as shown in Table 5, which resulted in a decision to reduce the number of analyses by not considering dam $\times$ number born. The somewhat surprising result (after seeing estimates for birth weight) was that none of the effects added to the basic model improved the likelihood. In fact, estimates for the four "extra" factors accounted uniformly for little or no variation. This may be partially explained by the management strategy of limiting the number of lambs suckled by a ewe to a maximum of two to increase lamb survival to weaning under open-range conditions. Artificial limitation on the number of lambs suckled could reduce the variance due to dam $\times$ year effects. There was a lack of significance of $r_{a m}$ based on the LRT. For consistency, $r_{a m}$ was included in all other models.
The models with and without genetic groups were only slightly more different than for birth weight. Again no evidence was found for variance due to cytoplasmic or genotype $\times$ cytoplasmic effects. Maniatis and Pollott (2002), with a model including maternal effects and cytoplasmic effects for 8-wk and 146-d weights, found no evidence of variance due to cytoplasmic effects. For weaning weight, there was no evidence of dominance variance.

\section{Fleece Weight}

Estimates of proportional variances are shown in Table 6 . Both individual and maternal permanent environmental effects were included in the first analyses. Although the maternal genetic and permanent environmental effects were thought, from previous analyses, to have no effect on the phenotypic expression of fleece weight in mature ewes, for consistency with the other traits, these effects were included in the model. The variance due to maternal permanent effects was near zero, so that factor was dropped from further analyses. The estimate of maternal heritability was low, about 0.02 , but made a significant contribution to the model, as indicated by the LRT and the standard error. The direct-maternal genetic covariance was not included in the model because of the low maternal heritability. Estimates of direct and maternal heritabilities were essentially the same no matter what other effects were 
Table 5. Estimates of genetic parameters ${ }^{\mathrm{a}}$ for weaning weight with 12 models with SE for complete model $^{\mathrm{b}}$ on bottom row

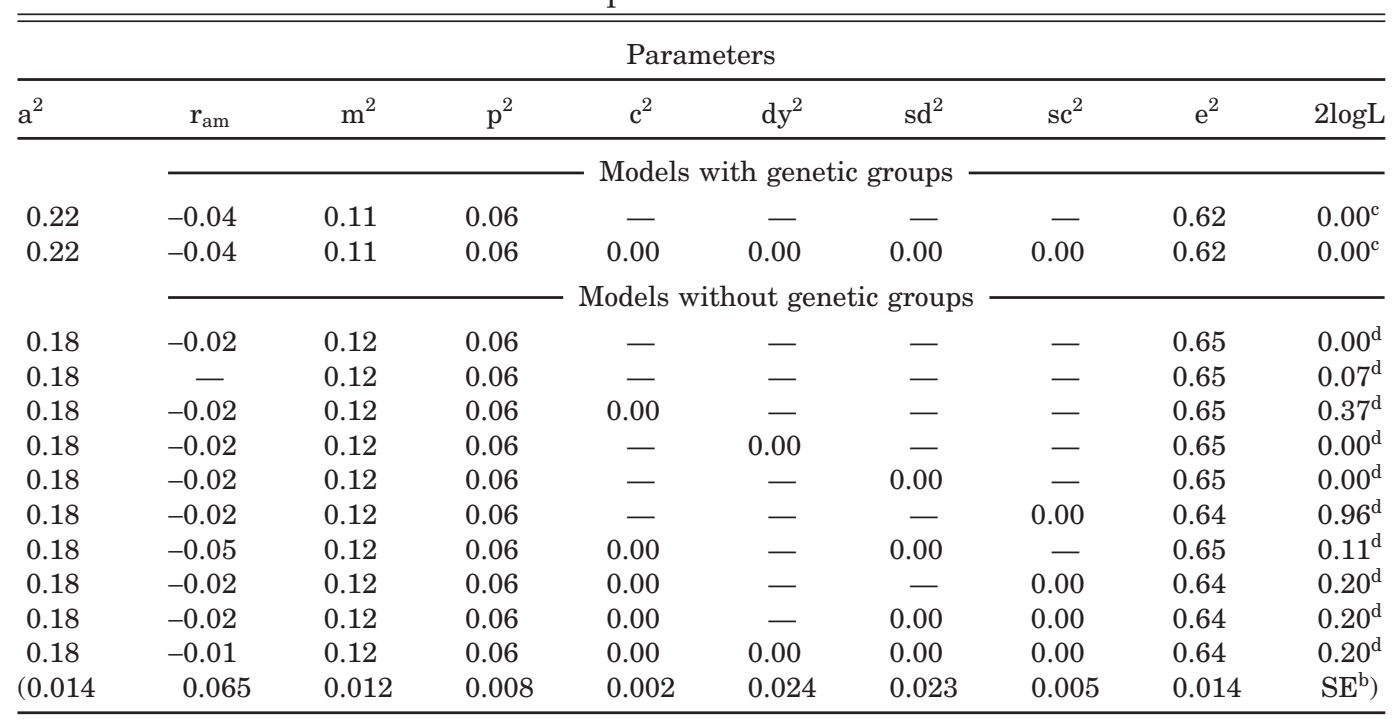

aproportional variance: $\mathrm{a}^{2}=$ direct genetic; $\mathrm{r}_{\mathrm{am}}=$ direct-maternal genetic correlation; $\mathrm{m}^{2}=$ maternal genetic; $\mathrm{p}^{2}=$ maternal permanent environmental; $\mathrm{c}^{2}=$ cytoplasmic line; $\mathrm{dy}^{2}=$ dam $\times$ year; $\mathrm{sd}^{2}=$ sire $\times$ dam; $\mathrm{sc}^{2}=$ sire $\times$ cytoplasmic line; $\mathrm{e}^{2}=$ temporary environmental.

${ }^{b}$ Complete model not including genetic groups. Phenotypic variance: 25.29 to $25.84 \mathrm{~kg}^{2}$.

'Difference in $2 \log$ likelihood from usual model $\left(\mathrm{a}^{2}, \mathrm{r}_{\mathrm{am}}, \mathrm{m}^{2}, \mathrm{p}^{2}\right)$ with genetic groups in model.

${ }^{\mathrm{d}}$ Difference in $2 \log$ likelihood from usual model $\left(\mathrm{a}^{2}, \mathrm{r}_{\mathrm{am}}, \mathrm{m}^{2}, \mathrm{p}^{2}\right)$ with genetic groups not in model.

included in the model. Similarly, estimates of proportional variances were the same, regardless of whether genetic groups were in the models. As with the other traits, variance due to cytoplasmic lines was near zero. Sire $\times$ dam effects also contributed nothing to variation. Addition of both dam $\times$ year and sire $\times$ cytoplasmic line effects to the model increased the likelihood. Variances due to these effects seemed to be partitioned from the variance due to individual permanent environmental effects, which suggests that for prediction of genetic values, a model including direct and maternal genetic values and individual permanent environmental effects would be sufficient. The small maternal genetic effect on fleece weight may be explained by the influence of postnatal nutrition of lambs on the capacity of wool follicles to produce fiber (Corbett, 1979).

\section{Number Born}

The estimates of proportional variance are shown in Table 7. As with the previous traits, estimates of vari-

Table 6. Estimates of genetic parameters ${ }^{a}$ for fleece weight with nine models with SE for complete model ${ }^{b}$ on bottom row

\begin{tabular}{|c|c|c|c|c|c|c|c|c|c|}
\hline \multicolumn{10}{|c|}{ Parameters } \\
\hline$a^{2}$ & $\mathrm{~m}^{2}$ & $\mathrm{p}_{\mathrm{m}}{ }^{2}$ & $\mathrm{p}^{2}$ & $c^{2}$ & $d y^{2}$ & $\mathrm{sd}^{2}$ & $\mathrm{sc}^{2}$ & $\mathrm{e}^{2}$ & $2 \log \mathrm{L}$ \\
\hline & & & & \multicolumn{3}{|c|}{ Models with genetic groups } & & & \\
\hline 0.56 & 0.02 & 0.00 & 0.10 & - & - & - & - & 0.33 & $0.00^{\mathrm{c}}$ \\
\hline 0.56 & 0.02 & 0.00 & 0.03 & 0.00 & 0.05 & 0.00 & 0.02 & 0.32 & $19.83^{\mathrm{c}}$ \\
\hline 0.57 & 0.02 & 0.00 & 0.09 & \multicolumn{3}{|c|}{ Models without genetic groups } & - & 0.31 & $0.00^{\mathrm{d}}$ \\
\hline 0.59 & - & 0.00 & 0.10 & - & - & - & - & 0.32 & $11.33^{\mathrm{d}}$ \\
\hline 0.57 & 0.01 & - & 0.02 & - & 0.07 & - & - & 0.32 & $18.67^{\mathrm{d}}$ \\
\hline 0.58 & 0.02 & - & - & - & 0.09 & - & - & 0.31 & $17.67^{\mathrm{d}}$ \\
\hline 0.57 & 0.02 & - & 0.05 & - & - & - & 0.04 & 0.31 & $16.36^{\mathrm{d}}$ \\
\hline 0.57 & 0.02 & - & 0.02 & - & 0.05 & - & 0.02 & 0.31 & $22.52^{\mathrm{d}}$ \\
\hline 0.57 & 0.02 & 0.00 & 0.02 & 0.00 & 0.05 & 0.00 & 0.02 & 0.31 & $22.51^{\mathrm{d}}$ \\
\hline$(0.016$ & 0.008 & 0.008 & 0.019 & 0.003 & 0.040 & 0.040 & 0.012 & 0.005 & $\mathrm{SE})^{\mathrm{b}}$ \\
\hline
\end{tabular}

aProportional variance: $\mathrm{a}^{2}=$ direct genetic; $\mathrm{m}^{2}=$ maternal genetic; $\mathrm{p}_{\mathrm{m}}{ }^{2}=$ maternal permanent environmental; $\mathrm{p}_{\mathrm{a}}{ }^{2}=$ permanent environmental; $\mathrm{c}^{2}=$ cytoplasmic line; $\mathrm{dy}^{2}=$ dam $\times$ year; $\mathrm{sd}^{2}$, sire $\times$ dam; $\mathrm{sc}^{2}=\operatorname{sire} \times$ cytoplasmic line; $\mathrm{e}^{2}=$ temporary environmental. Phenotypic variance: 0.6992 to $0.7114 \mathrm{~kg}^{2}$.

${ }^{\mathrm{b}}$ Complete model not including genetic groups.

'Difference in 2log likelihood from usual model $\left(\mathrm{a}^{2}, \mathrm{~m}^{2}, \mathrm{p}_{\mathrm{m}}{ }^{2}, \mathrm{p}_{\mathrm{a}}{ }^{2}\right)$ with genetic groups in model.

${ }^{\mathrm{d}}$ Difference in $2 \log$ likelihood from usual model $\left(\mathrm{a}^{2}, \mathrm{~m}^{2}, \mathrm{p}_{\mathrm{m}}{ }^{2}, \mathrm{p}_{\mathrm{a}}{ }^{2}\right)$ with genetic groups not in model. 
Table 7. Estimates of genetic parameters ${ }^{\mathrm{a}}$ for number born with nine models with SE for complete model ${ }^{\mathrm{b}}$ on bottom row

\begin{tabular}{|c|c|c|c|c|c|c|c|c|c|}
\hline \multicolumn{10}{|c|}{ Parameters } \\
\hline$a^{2}$ & $\mathrm{~m}^{2}$ & $\mathrm{p}_{\mathrm{m}}{ }^{2}$ & $\mathrm{p}_{\mathrm{a}}{ }^{2}$ & $c^{2}$ & $d y^{2}$ & $\mathrm{sd}^{2}$ & $\mathrm{sc}^{2}$ & $\mathrm{e}^{2}$ & $2 \log \mathrm{L}$ \\
\hline & & & & \multicolumn{6}{|c|}{ Models with genetic groups } \\
\hline 0.10 & 0.00 & 0.00 & 0.04 & - & - & - & - & 0.86 & $0.00^{c}$ \\
\hline 0.10 & 0.00 & 0.00 & 0.01 & 0.00 & 0.02 & 0.00 & 0.01 & 0.86 & $5.86^{\mathrm{c}}$ \\
\hline & & & & \multicolumn{3}{|c|}{ Models without genetic groups } & & & \\
\hline 0.10 & 0.00 & 0.00 & 0.04 & - & - & - & - & 0.85 & $0.00^{\mathrm{c}}$ \\
\hline 0.10 & - & 0.00 & 0.01 & - & 0.02 & - & 0.01 & 0.85 & $9.93^{\mathrm{d}}$ \\
\hline 0.10 & - & - & 0.01 & - & 0.02 & - & 0.01 & 0.85 & $9.93^{\mathrm{d}}$ \\
\hline 0.10 & - & - & 0.01 & - & 0.03 & - & - & 0.85 & $6.75^{\mathrm{d}}$ \\
\hline 0.10 & - & - & 0.02 & - & - & - & 0.02 & 0.85 & $7.73^{\mathrm{d}}$ \\
\hline 0.10 & 0.00 & 0.00 & 0.01 & 0.00 & 0.02 & 0.00 & 0.01 & 0.85 & $10.04^{\mathrm{d}}$ \\
\hline$(0.008$ & 0.004 & 0.005 & 0.013 & 0.001 & 0.032 & 0.003 & 0.008 & 0.006 & $\mathrm{SE})^{\mathrm{b}}$ \\
\hline
\end{tabular}

aproportional variance: $\mathrm{a}^{2}=$ direct genetic; $\mathrm{m}^{2}=$ maternal genetic; $\mathrm{p}_{\mathrm{m}}{ }^{2}=$ maternal permanent environmental; $\mathrm{p}_{\mathrm{a}}{ }^{2}=$ permanent environmental; $\mathrm{c}^{2}=$ cytoplasmic line; $\mathrm{dy}^{2}=$ dam $\times$ year; $\mathrm{sd}^{2}=$ sire $\times$ dam; $\mathrm{sc}^{2}=\operatorname{sire} \times$ cytoplasmic line; $\mathrm{e}^{2}=$ temporary environmental. Phenotypic variance: 0.3877 to 0.3908 .

${ }^{b}$ Complete model not including genetic groups.

'Difference in 2log likelihood from usual model $\left(\mathrm{a}^{2}, \mathrm{~m}^{2}, \mathrm{p}_{\mathrm{m}}{ }^{2}, \mathrm{p}_{\mathrm{a}}{ }^{2}\right)$ with genetic groups in model.

${ }^{\mathrm{d} D i f f e r e n c e}$ in $2 \mathrm{log}$ likelihood from usual model $\left(\mathrm{a}^{2}, \mathrm{~m}^{2}, \mathrm{p}_{\mathrm{m}}{ }^{2}, \mathrm{p}_{\mathrm{a}}{ }^{2}\right)$ with genetic groups not in model.

ance due to cytoplasmic effects were near zero. Estimates of proportional variance were the same regardless of whether genetic groups were included in the model, and direct heritability was the same with all models. No evidence was found for variation due to maternal genetic or permanent environmental effects. Including both dam $\times$ year and sire $\times$ cytoplasmic line effects partitioned variance from the relatively small component of variance due to animal permanent environmental effects. The variance due to dam $\times$ year effects was less than its standard error, and variance due to sire $\times$ cytoplasmic line effects was about the same size as its standard error. For genetic evaluation, a model with direct genetic value and animal permanent environmental effects would seem to be adequate. The estimates of variance components and likelihood for that model would be the same as rows 1 and 3 of Table 7. Those estimates are nearly the same as those reported by Rao and Notter (2000).

\section{Discussion}

Cytoplasmic line effects are not important for any of the four traits analyzed. Variance due to the interaction of nuclear and cytoplasmic genomes modeled as sire $x$ cytoplasmic line effects was near zero for birth weight. Small, but nonzero, estimates for other traits could be due to confounding with other interaction effects. For genetic evaluations for weaning weight, the standard maternal effects model, perhaps ignoring the direct maternal genetic correlation, would be optimal. For fleece weight, a model with direct animal and maternal genetic effects with an animal permanent environmental effect would be sufficient. For number born, a model with direct animal genetic and permanent environmental effects would be adequate.
The results for birth weight (probably a less important trait economically than the other traits) are puzzling. Of the nontraditional factors added to the model, only cytoplasmic and sire $\times$ cytoplasmic effects did not improve the model. The other three interaction effects are highly confounded, but each seems to account for about 0.05 of phenotypic variance and to jointly reduce residual variance by about one-quarter from 0.45 to 0.35 of phenotypic variance. The maternal (dam) permanent environmental variance is decreased by about one-half (from 0.08 to 0.04 or 0.05 of phenotypic variance) when the interaction of dam $\times$ year or dam $\times$ number born is included in the model. Including sire $\times$ dam effects in the model only slightly reduced the maternal permanent environmental variance, but including dam $\times$ year effects reduced the sire $\times$ dam component of variance from 0.11 to 0.05 of phenotypic variance. A nonzero estimate for the sire $\times$ dam component of variance with other effects in the model suggests that dominance effects may be important for birth weight. The reassuring aspect of the analyses of birth weight is that estimates of the basic genetic parameters were not affected by adding nontraditional factors to the model. Although more study is needed, this result suggests that the standard model with addition of a dam $\times$ year (litter) effect (Al-Shorepy and Notter, 1998) would be relatively robust for ranking on estimated genetic values. Standard errors of prediction, however, would be expected to be reduced by accounting for a larger fraction of the residual variance by including the various interactions with dams. Further study seems warranted to explain why dam by year effects in the model resulted in a large improvement in the likelihood. Of interest would be whether analyses of records of other breeds would give a similar pattern of estimates of variance components. 


\section{Implications}

Cytoplasmic effects appear unimportant for birth, weaning, and fleece weight and number of lambs born, and for this population, would not need be considered in the model for genetic evaluations. Models for genetic evaluation of ewes for weaning weight and fleece weight and number of lambs born do not need to include interactions between dams and years or dams and sires (i.e., standard models including direct and maternal genetic effects and, as appropriate, either direct or maternal permanent environmental effects are adequate). Further study is needed to unravel the puzzling results for birth weight, which show that interactions of dam with year, number born, and sire are statistically important.

\section{Literature Cited}

Albuquerque, L. G., J. F. Keown, and L. D. Van Vleck. 1998. Variances of direct genetic effects, maternal genetic effects, and cytoplasmic inheritance effects for milk yield, fat yield, and fat percentage. J. Dairy Sci. 81:544-549.

Al-Shorepy, S. A., and D. R. Notter. 1998. Genetic parameters for lamb birth weight in spring and autumn lambing. Anim. Sci. 67:327-332

Bell, B. R., B. T. McDaniel, and O. W. Robison. 1985. Effects of cytoplasmic inheritance on production traits of dairy cattle. J. Dairy Sci. 68:2038-2051.

Boettcher, P. J., A. E. Freeman, S. D. Johnson, R. K. Smith, D. C. Beitz, and B. T. McDaniel. 1996. Relationships between polymorphism for mitochondrial deoxyribonucleic acid and yield traits of Holstein cattle. J. Dairy Sci. 79:647-654.

Boettcher, P. J., and J. P. Gibson. 1997. Estimation of variance of maternal lineage effects among Canadian Holsteins. J. Dairy Sci. 80:2167-2176.

Boldman, K. G., L. A. Kriese, L. D. Van Vleck, C. P. Van Tassell, and S. D. Kachman. 1995. A Manual for Use of MTDFREML. USDA-ARS, Clay Center, NE.

Corbett, J. L. 1979. Variation in wool growth with physiological state. Pages 79-98 in Physiological and Environmental Limitations to Wool Growth. J. L. Black and P. J. Reis, ed. Univ. New England Pub.

Dodenhoff, J., L. D.Van Vleck, S. D. Kachman, and R. M. Koch. 1998. Parameter estimates for direct, maternal and grandmaternal genetic effects for birth weight and weaning weight in Hereford cattle. J. Anim. Sci. 76:2521-2527.
Dodenhoff, J., L. D. Van Vleck, and D. E. Wilson. 1999. Comparison of models to estimate genetic effects for weaning weight of Angus cattle. J. Anim. Sci. 77:3176-3184.

Ercanbrack, S. K., and A. D. Knight. 1991. Effects of inbreeding on reproduction and wool production of Rambouillet, Targhee, and Columbia ewes. J. Anim. Sci. 69:4734-4744.

Hagger, C. 1998. Litter, permanent environmental, ram-flock, and genetic effects on early weight gain of lambs. J. Anim. Sci. 76:452-457.

Hanford, K. J. 2001. Estimates of genetic parameters and genetic change for prolificacy, weight, and wool characteristics of Columbia, Targhee and Polypay sheep. Ph.D. Diss. Univ. of Nebraska, Lincoln.

Kennedy, B. W. 1986. A further look at evidence for cytoplasmic inheritance of production traits in dairy cattle. J. Dairy Sci. 69:3100-3105.

Lee, C., and E. J. Pollak. 1997. Relationship between sire x year interactions and direct-maternal genetic correlation for weaning weight of Simmental cattle. J. Anim. Sci. 75:68-75.

Maniatis, N., and G. E. Pollott. 2002. Nuclear, cytoplasmic, and environmental effects on growth, fat, and muscle traits in Suffolk lambs from a sire referencing scheme. J. Anim. Sci. 80:57-67.

Mannen, H., T. Kojima, K. Oyama, F. Mukai, T. Ishida, and S. Tsuji. 1998. Effect of mitochondrial DNA variation on carcass traits of Japanese Black Cattle. J. Anim. Sci. 76:36-41.

Rao, S., and D. R. Notter. 2000. Genetic analysis of litter size in Targhee, Suffolk, and Polypay sheep. J. Anim. Sci. 78:21132120.

Robinson, D. L. 1996. Models which might explain negative correlations between direct and maternal genetic effects. Livest. Prod. Sci. 45:111-122.

Schutz, M. M., A. E. Freeman, G. L. Lindberg, C. M. Koehler, and D. C. Beitz. 1994. The effect of mitochondrial DNA on milk production and health of dairy cattle. Livest. Prod. Sci. 37:283-295.

Seelan, R. S., and L. I. Grossman. 1992. Structure and organization of the heart isoform gene for bovine cytochrome c oxidase subunit VIIa. Biochemistry 31:4969-4704.

Smith, S. P., and H.-U. Graser. 1986. Estimating variance components in a class of mixed models by restricted maximum likelihood. J. Dairy Sci. 69:1156-1165.

Tess, M. W., C. Reodecha, and O. W. Robison. 1987. Cytoplasmic genetic effects on preweaning growth and milk yield in Hereford cattle. J. Anim. Sci. 65:675-684.

Tess, M. W., and O. W. Robison. 1990. Evaluation of cytoplasmic genetic effects in beef cattle using an animal model. J. Anim. Sci. 68:1899-1909.

Westell, R. A., R. L. Quaas, and L. D. Van Vleck. 1988. Genetic groups in an animal model. J. Dairy Sci. 71:1310-1318.

Wolz,W., W. Kress, and C. R. Mueller. 1997. Genomic sequence and organization of the human gene for cytochrome c oxidase subunit (COX7A1) VIIa-M. Genomics 45:438-442. 